\title{
Proportionality Review in Administrative Law
}

Jud Mathews

Follow this and additional works at: http://elibrary.law.psu.edu/book_contributions

Part of the Administrative Law Commons

\section{Recommended Citation}

Mathews, Jud, "Proportionality Review in Administrative Law" (2017). Contributions to Books. 9.

http://elibrary.law.psu.edu/book_contributions/9

This Book is brought to you for free and open access by the Faculty Works at Penn State Law eLibrary. It has been accepted for inclusion in Contributions to Books by an authorized administrator of Penn State Law eLibrary. For more information, please contact ram6023@psu.edu. 


\section{Proportionality Review in Administrative Law}

Jud Mathews ${ }^{1}$

(forthcoming in Comparative Administrative Law, second edition (Peter Lindseth, Susan Rose-Ackerman \& Blake Emerson, eds.), Northampton: Edward Elgar, 2017.)

\section{Introduction}

At the most basic level, the principle of proportionality captures the common-sensical proposition that, when the government acts, the means it chooses should be well-adapted to achieve the ends it is pursuing. The proportionality principle is an admonition, as German administrative law scholar Fritz Fleiner famously wrote many decades ago, that "the police should not shoot at sparrows with cannons" (Fleiner 1928, 404). Courts instantiate the principle through a form of review that typically passes a challenged legal measure through a prescribed sequence of increasingly stringent legal tests, in order to determine whether the measure in fact impinges disproportionately on the rights or interests of a party.

The global spread of proportionality is one of the worst-kept secrets in comparative law. As proportionality has become a fixture in numerous national and international legal regimes over the past few decades (Stone Sweet and Mathews 2008), it has also attracted a substantial amount of scholarly attention, and more than a little criticism. ${ }^{2}$ But the lion's share of attention has focused on the use of proportionality in the realm of constitutional law, as a technique for adjudicating constitutional rights claims. Scholars have also given substantial consideration to the use of proportionality in regimes of public international law and and international investment law (Baade et al. 2016; Bücheler 2015). Less has been said about proportionality's role within administrative law. In fact, proportionality has also come to play a significant role in the administrative law of a large and diverse set of jurisdictions as a control on administrative discretion, even when constitutional rights are not in play.

If the use of proportionality review in administrative law is widespread, it is also characterized by significant national differences. This chapter 
aims to survey that diversity, and to help make sense of it, by organizing it and offering hypotheses about some of the sources of the variation that we observe. I draw on examples from several jurisdictions, but I do not claim that this account is remotely comprehensive or definitive. ${ }^{3}$ The use of proportionality review in administrative law is a topic that deserves more thorough and systematic study. ${ }^{4}$ Further empirical work would permit, among other things, testing of the hypotheses tentatively offered in this chapter.

Proportionality in administrative law is something of a moving target, as changes are ongoing in many legal systems. Still, I suggest that we can understand the differences in how proportionality is used in the administrative law of different jurisdictions in terms of three principal axes of variation. With respect to any jurisdiction, we can ask:

- how extensive the use of proportionality is (for instance, is proportionality applied haphazardly, or only in a few settings, or is it a general head of review that applies in principle to all administrative actions?),

- how intensive the application of proportionality is (for instance, does proportionality entail serious judicial scrutiny, or substantial deference, or does it amount in practice to a lowintensity reasonableness review?), and

- how discursive proportionality review is within the jurisdiction (for instance, do courts treat proportionality as a framework for reasoned justification, through which they explain their way to a conclusion in light of the relevant factors, or is the conclusion that a measure is proportional presented as an ipse dixit?)

Ultimately, I argue, we can resolve some of the cross-national variety that we see into intelligible patterns, at which point some underlying regularities in how proportionality is used begin to emerge. To be sure, the diversity is very real: not only in formal doctrinal structures, but even in what actors in different legal systems mean when they refer to "proportionality" or "balancing" (Bomhoff 2013, 13-21). But it becomes possible to think of proportionality as a master concept of public law, and to see the differences in how it is instantiated-within different legal systems, in constitutional versus administrative law, and in different contexts within administrative 
law-as adaptations to system- and context-specific differences.

The next section discusses the steps of proportionality review, and its historical origins. The section following describes the three major axes of variation. The last section assesses differences in how proportionality is applied, both across and within legal systems, and in conclusion considers proportionality's place in public law.

\section{Proportionality Review: Elements and Origins}

\subsection{The Elements of Proportionality Review}

What I will call the standard model of proportionality review consists of three or four steps, depending on who is doing the counting. Courts inquire successively into the (1) legitimacy, (2) suitability, (3) necessity, and (4) proportionality stricto sensu-in the strict sense-of a challenged measure. (In many jurisdictions, the first step is regarded as a threshold inquiry, rather than a part of the analysis proper).

Suppose, for instance, that the Minister of Transportation issues regulations banning most heavy goods trucks from highways during daytime weekend hours. A full-dress review of the measure's proportionality might look something like the following. First, as a

preliminary matter, the court would ask whether the challenged measure serves a legitimate purpose: that is to say, a purpose it is permissible for the authority in question to pursue. This is a low bar to pass-it is a serious and rare infirmity for a government measure to have no legitimate purpose-and few measures are struck down at this stage. The Ministry should be able to justify the measure as a means to pursue ends for which it is responsible: reducing road congestion and improving public safety, for instance.

Next, the court asks whether the challenged measure is a "suitable" means to the achievement of its purpose. This, too, is a fairly relaxed inquiry, similar in spirit to the rational basis review conducted by American courts. To qualify as suitable, a measure need not be the best possible or most appropriate; it need only make some contribution to the legitimate purpose already identified. If the Ministry can credibly 
claim that the ban reduces congesting and improves safety, it will pass this test.

From this point on, proportionality review becomes progressively more demanding —although in practice, just how demanding can vary quite a bit. The next question is whether the measure is necessary to achieve its stated goal. This necessity inquiry is often operationalized as a leastrestrictive means test: in other words, could the government's purpose also be achieved by alternative measures that infringe less on the freedom or interests of others? If the answer is yes, the government's action is a disproportionate measure, and hence impermissible.

Whether our putative driving ban would survive this stage of review depends heavily on how the court conducts it. Least-restrictive means testing is, in principle, quite an intensive form of judicial scrutiny. But as discussed further below, courts in different jurisdictions have been known to modulate the stringency of the inquiry, for instance by adjusting how much deference they give to government judgments about the effects and availability of policy alternatives.

If a measure survives the necessity test, it proceeds to the final phase of the inquiry, a balancing analysis, also known as "proportionality in the strict sense." Now the court weighs the benefits of the challenged measure (which has already been found to be appropriately tailored to the end it serves) against its costs, in terms of infringements of protected rights or interests. Only if its benefits exceed the burden it imposes does the challenged measure survive. Obviously, in this final stage of the analysis, courts cannot avoid making policy assessments and value judgments.

\subsection{Origins of Proportionality Review}

The core idea of proportionality, of course, a very old one. In a concurrence, Israel's Supreme Court President Aharon Barak found a version of the concept in twelfth-century philosopher Moses Maimonides' instruction to use stronger medicines only if weaker medicines fail, ${ }^{5}$ and has identified still older antecedents in his scholarly work (Barak 2012). And courts have applied at least some version of a proportionality test for a long time as well. Paul Craig has recently unearthed a trove of sixteenth and seventeenth-century 
English cases in which courts apply a "proportionability" standard in a number of contexts (Craig 2017).

But the modern, multistep proportionality framework is an innovation of Germany's Federal Constitutional Court, which has used it to adjudicate constitutional rights claims for more than half a century. And the Constitutional Court adapted the concept from German administrative law, where proportionality has played a role in judicial control of administrative action since the late nineteenth century. It is worth taking a very brief trip through proportionality's origins in German legal thought and judicial practice, because the original justifications offered for proportionality as a fundamental legal principle still resonate today, or so I will suggest later.

The proportionality principle emerged when late-eighteenth century legal thinkers derived rules to govern the use of police power in light of first principles of political philosophy. By the late 1700s, cameralism - the German science of public administration-had largely accepted the social contractarian premise that state power rests on an implicit bargain between subjects and sovereign, whereby the former submit to the rule of the latter so that the sovereign can advance their common welfare. But if this bargain is the source of the state's authority to act, it also sets the outer bounds of the state's authority: the state is justified in acting only to the extent that its action promotes the public welfare. As applied to police law, in the words of jurist Günther Heinrich von Berg, "the police law may abridge the natural freedom of the subject, but only insofar as its lawful goal requires."

If the principle of proportionality was recognized by the end of the eighteenth century, proportionality review would not develop until nearly a century later, after administrative acts became subject to review by courts. The key development here was the establishment in Prussia of the Supreme Administrative Court (Oberverwaltungsgericht) in 1875. Within a few years, the court had fashioned the proportionality principle into a meaningful constraint over administrative discretion, both by circumscribing the legitimate ends of the police power, and also by scrutinizing the means chosen in pursuit of those ends.

Two examples will suffice by way of illustrating the early 
proportionality case law of the Supreme Administrative Court. In an 1886 case, the court ruled that the police could not require, on public safety grounds, a landowner to remove a post erected at the edge of his property. Rather, all that was necessary to protect the public was requiring the landowner to light the post after dark. As the court explained, "[t]he protection from accidents . . . is indeed the task of the police; this task and the authority finds its limit, however, in that the chosen measures may not extends farther than they must to meet the goal of eliminating the danger." That same year, the court ruled that it was disproportionate, and hence, impermissible for the police to close down a shop in response to the shopowner's distribution of brandy without a license. The operation of the shop was itself not unlawful; only the distribution of brandy was. And so closing the shop was a more drastic step than the police needed to take to meet the legitimate goal of enforcing the license requirement.

Other administrative courts within Germany soon began following Prussia's lead, striking down police measures on proportionality grounds (Stern 1993, 168). Though the subjects of imperial Germany did not enjoy the protection of entrenched constitutional rights, proportionality did make a significant contribution to individual freedom and the rule of law, by regularizing the use of state power.

\section{Axes of Variation}

Today, a form of proportionality review plays at least some role in the administrative law of many legal systems, but the differences across jurisdictions are significant. I suggest that administrative law systems vary along three principal dimensions with respect to their use of proportionality review.

\subsection{Extensiveness of Use}

Administrative law systems differ in terms of how extensively they employ proportionality review. In some systems, proportionality is regarded as a constitutional or general principle of law that applies, in

principle, to the whole corpus of law. In others, proportionality applies only to certain areas within administrative law, or crops up 
unpredictably. And of course, some administrative law systems do not recognize proportionality as a governing legal standard at all.

The European Union and Germany stand at one end of the spectrum, as jurisdictions in which the proportionality principle counts as fundamental law. In the European Union, proportionality numbers among the general principles of EU law, and applies to EU measures as well as to member state measures alleged to infringe freedoms guaranteed in EU Treaties (Tridimas 2006, 137-38). Similarly, in Germany, proportionality counts as a fundamental constitutional principle, derived from the rule of law, which applies to all acts of the state that implicate the subjective rights of individuals in any way (Jarass and Pieroth 2012, 529, 530). ${ }^{6}$ More recently, South Korea's Constitutional Court has identified proportionality as a basic standard of review (Huang and Law 2014, 13).

Significantly, even in jurisdictions where proportionality applies in principle to all acts of the state, it does not follow that proportionality dominates the decisional law of administrative tribunals, providing the rule of decision in most cases. The array of rules and requirements to which the administration must conform in a typical jurisdiction tends to generate a correspondingly wide set of grounds on which to challenge administrative actions. Moreover, proportionality generally only comes into play where the administration is authorized to exercise discretion, and legal systems may recognize grounds for the substantive review of administrative choices in addition to proportionality.

Germany illustrates the point. Judicial review may be available of both regulations (Rechtsverordnungen) and concrete administrative acts (Verwaltungsakte - enforcement actions, for instance), but legal challenges to the latter predominate in German administrative law (Rose-Ackerman 1995, 60). German administrative law has welldeveloped doctrines in place to govern the use of different forms of discretion by the administration (Marsch and Tünsmeyer 2016, 19-21). Some administrative choices that could be challenged as disproportionate grounds would also qualify as a misuse of discretion (Ermessensfehlgebrauch) and so could be invalidated on that ground (Maurer 2011, 149-50). ${ }^{7}$ There are different views among scholars as to how the proportionality principle relates conceptually to the 
doctrines governing the use of discretion (Alexy 1986). But in administrative litigation, it seems that proportionality often ends up functioning as a last line of offense, to be litigated after other lines of attack against a measure fail, and when they are unavailable.

In other jurisdictions, the use of proportionality has been formally confined to one or a few areas within administrative law. In England, for instance, the venerable and deferential Wednesbury standard continues to govern most administrative decisions. Proportionality, however, applies to matters decided under EU law or the Human Rights Act of 1998, which enacted as domestic law rights from the European Convention on Human Rights (Davies and Williams 2016, 71). In Canada, proportionality informs the reasonableness review of administrative action insofar as it implicates rights guaranteed under Canada's Charter of Rights and Values. ${ }^{8}$ And even though judicial review of administrative discretion is extremely limited in China, proportionality has made some scattered appearances there as well, including in a decision of the Supreme People's Court, ${ }^{9}$ and significantly, in several lower court cases selected for publication in the anthology of Guiding Cases, which is edited by the Administrative Tribunal of Supreme People's Court (Wang 2013, 14-17). In some jurisdictions, including Taiwan and South Korea, proportionality has been taken up unevenly by different high courts (Huang and Law 2014, $13,21)$.

The adoption of proportionality in a jurisdiction, even to a limited extent, sometimes seems to trigger an expansion of proportionality's use, or at least calls for such an expansion. Its adoption in the constitutional context may pave the way for its use in administrative law (or vice versa). In the years since the adoption of the Human Rights Act in the UK, a number of scholars there have called for the adoption of proportionality as a general head of review (Craig 2013, 88 n.24), and proportionality has in fact made some inroads in administrative caselaw (Davies and Williams 2016, 80). ${ }^{10}$ With respect to Canada, scholars have advanced different arguments to the effect that courts should more tightly integrate administrative law doctrines and constitutional law principles, including proportionality (Walters 2015; Carter 2004). In recent years, proportionality has experienced increased recognition in a number of Asian jurisdictions, including 
Taiwan, Korea, and Japan as well as China, and may come to play a still more prominent role in those jurisdictions in years to come (Huang and Law 2014).

France is a jurisdiction where proportionality has come to be widely used in a number of areas of administrative law over a period of years (Sanchez 2016, 43-44). Police measures that infringe on basic freedoms have long been subject to a form of proportionality review administered by France's Conseil d'Etat, the highest administrative tribunal. For instance, in the celebrated Benjamin case from 1933, the Conseil d'Etat struck down a police measure banning a conference organized by a controversial political figure, on the grounds that less restrictive measures would have also preserved the peace. ${ }^{11}$

Starting in the 1970s, the Conseil d'Etat began assessing urban planning decisions under the doctrine of le bilan (the balance sheet), which amounts to a proportionality balancing analysis: the court compares the advantages and disadvantages of a given plan to determine whether it is permissible (Brown and Bell 1998, 263). Proportionality also figures importantly in the review of administrative penalties in France. ${ }^{12}$ The Conseil d'Etat also appears to be becoming more self-conscious is its use of the proportionality concept in recent years: comparing the years 2001-2005 and 2010-2015, references to "proportionnalité" in the decisions of the Conseil d'Etat jumped roughly five-fold, while the volume of decisions overall declined by more than a third. And notably, France's Constitutional Council began explicitly conducting proportionality review on legislation in $2008 .^{13}$

\subsection{Intensity of Application}

Applied at full strength, proportionality review sets a very demanding standard. As mentioned above, its real teeth are to be found in the penultimate and final steps of the test's canonical formulation, which subject the challenged measure to least restrictive means testing and a form of benefit-cost analysis, respectively. In practice though, there is substantial variation, across jurisdictions and across contexts, in how intensively proportionality is applied.

Writing with reference to the Human Rights Act, Cora Chan has inventoried a number of techniques UK courts have employed to 
soften the stringency of proportionality review. These include: skipping stages of the analysis or merging it into an omnibus "fair balance" or "reasonableness" review; granting some measure of deference to the primary decision maker's judgment, either of the availability of lessinfringing alternatives or the proportionality of the measure more broadly; and limiting review to cases of "manifest disproportionality" (Chan 2013,9). These techniques appear in other jurisdictions as well, alongside some others, such as shifting to a measure's challenger the burden of demonstrating the availability of less onerous alternatives (De Búrca 1993, 111-12).

In some jurisdictions, proportionality is rarely if ever applied in a very demanding form. In China, for example, Jing Wang reports that courts in China are reluctant to review discretionary decisions with substantial stringency, even in the rare instances where they are in a position to invoke proportionality at all (Wang 2013, 18-19). Elsewhere, courts appear to oscillate between more and less intensive versions of proportionality with little predictability. Describing the use of proportionality by Taiwan's Constitutional Court, Cheng-yi Huang and David Law write that "the test remains underdeveloped and inconsistent in application" (Huang and Law 2014, 20). In systems where proportionality review is well-established, however, courts tend to vary the scrutiny of review with the context of the case in a moreor-less predictable fashion.

The EU offers a good example. The degree of scrutiny that the Court of First Instance and the European Court of Justice applies varies across the range of cases the courts hear, in light of the relative competences of courts and legislatures and the importance of the issues the courts are charged to protect (Craig 2006, 657). Judicial scrutiny is at a low ebb when the courts review discretionary choices that require political, social, and economic judgments and trade-offs. ${ }^{14}$ In such cases, the courts generally overturn only those directives or regulations found to be "manifestly disproportionate." The courts tend to be less deferential, for instance, when reviewing burdens and penalties, which often pose substantial hardships for the individual challengers and do not usually implicate the design of broader regulatory programs (Craig 2006, 681). ${ }^{15}$ A claim that a measure violates an EU right triggers highintensity review (Craig and De Búrca 2011, 546). Predicting the degree 
of scrutiny may become more difficult to the extent that a case features factors that augur both for stepped-up and stepped-down scrutinysay, a broadly discretionary policy choice that allegedly violates a right (Craig and De Búrca 2011, 546).

Varying the level of scrutiny with the case characteristics is a way the proportionality framework can be made to respect a number of values relevant to the administrative process or policy goals. For instance, in Japan, courts apply a notably deferential version of proportionalitystyle review to administrative decisions not to act (Chikushi 2013). This directional deference-more pronounced towards agency inaction than action-reflects a sensitivity to the administration's inherent advantage, relative to courts, in setting regulatory and enforcement priorities. EU courts make room for the precautionary principle in proportionality review insofar as it touches on the regulation of risk, by reviewing aggressive measures to reduce risks of serious harm with a fairly light touch (Craig 2006, 662).

\subsection{Discursiveness of Analysis}

Jurisdictions also differ in the extent to which courts use proportionality review to structure an in-depth discourse on the challenged measure. Proportionality offers a framework that courts can use to engage in detail and at length with the merits and faults of a measure, as put before the court by the contending parties. In working their way through the proportionality subtests, courts can build a reasoned justification for their rulings, acknowledging the competing interests on either side and explaining why, ultimately, one side prevails. (Stone Sweet and Mathews 2008, 89). But proportionality review is not always and everywhere employed so discursively. At the other extreme, courts can make bare assertions that measures are proportionate, or reward measures that survive some other kind of review with that label (Lin 2013, 14, 18-20).

There may be a connection between the intensity and discursiveness of a court's proportionality review. As described above, courts can moderate the intensity of review by shedding stages of the analysis or compressing them into a less invasive "reasonableness" review. But lowering the intensity of proportionality review does not necessarily entail sacrificing a deliberative, detailed evaluation of the competing 
claims or a well-justified conclusion. As Paul Craig notes, even when they review measures under the fairly deferential "manifest disproportionality" approach, the Courts of the EU nonetheless engage in thorough, reasoned evaluation of the measures before them (Craig 2006, 670). What would be surprising, on the other hand, would be for a court to reject a measure as disproportionate, without justifying that outcome by amply demonstrating the course of reasoning that led it to that conclusion-including, for instance, by pointing to less infringing alternatives the government could have chosen.

Existing national norms of judicial practice will certainly shape how courts present their proportionality analysis, but proportionality itself may have some impact on judicial culture. France is an interesting case in point. Ruling from France's high courts tend to be short and syllogistic, presenting their conclusions as the inevitable results of inexorable operations of deductive logic (Lasser 2005, 34). Structurally, the decisions consist of a series of "Whereas" clauses, terminating in an announcement of the court's judgment. It is not that French courts do not engage in wide-ranging deliberations about the cases that they hear. They do, but these are typically conducted in ancillary documents that do not form a part of their published decisions (Lasser 2005, 47-60). The analysis in the decision itself may be skeletal in the extreme. France's Constitutional Council, for instance, often concludes in a single sentence that a challenged measure is necessary, adequate, and proportionate (Sanchez 2016, 44). ${ }^{16}$

Still, the French administrative courts have shown that they can engage in a form of proportionality formula even within the confines of the syllogistic formula. They can do so by shoehorning the case-specific circumstances that guide their evaluation of a challenged measure's fit into that formula. In an unpublished decision from early 2016, for instance, the Conseil d'Etat reviewed a challenge, on proportionality and other grounds, to a police order ordering the eviction of all those camped on public lands in a suburb of Paris within 48 hours. ${ }^{17}$ The Conseil disposed of the proportionality challenge in a long "Whereas" clause, the longest of the decision by far, that noted the dramatic recent increase in the encampments' population, uncontroverted police reports noting unsafe and unsanitary conditions in the camps, and the 
city's provision of emergency housing for the camp's residents before concluding that there was no "manifest breach of the conditions of necessity and proportionality."

Germany makes for an interesting comparison with France. German administrative court decisions can be exercises in sustained justification, with detailed consideration given to the relevant law and facts before the court. Accordingly, it is not surprising to find fairly indepth proportionality analyses in German administrative caselaw. ${ }^{18}$ But notably, the courts do not engage in detailed analysis in all cases where the pass on the proportionality of a challenged measure. In circumstances where proportionality is not one of the major issues or the case, or the question is not a close one, German courts can also dispense with proportionality arguments quite briskly. ${ }^{19}$

There may be some jurisdictions in which a conclusion that a measure is proportionate is sometimes little more than a naked assertion not fortified by further reasons. Writing about Taiwan, for instance, and specifically with reference to environmental litigation, Chun-Yuan Lin has characterized proportionality as a "meaninglessly mentioned principle" $(2013,13)$.

Wherever courts conduct proportionality review, they of course do so against a backdrop of system-specific norms about the form of judicial decisions. But it is notable that, even given these differences, courts in different jurisdictions find the latitude to expand or contract the discursiveness of proportionality analysis, as they deem the circumstances of a case to demand.

\section{Assessment}

\subsection{Patterns}

Broadly surveying the use of proportionality review in administrative law across jurisdictions, the first impression is one of a great diversity of approaches, across a number of dimensions: in terms of when, how, and how stringently the review is conducted. And to be sure, there are some pronounced national differences. And of course, there are many 
systems that do not recognize proportionality as a head of review at all (even if, in some cases, they have doctrines that approximate proportionality review in some respects (Mathews 2016)).

But a closer look reveals that there are substantial variations within legal systems as to how proportionality review is conducted in different circumstances. And at least some of the variation, within and across systems, begins to resolve itself into some broad patterns. In the space remaining, I will describe some of the patterns, and conclude with some comments about what this suggests about the role of proportionality in public law more generally.

\section{1.a Extensiveness}

Systems vary with respect to how extensively they employ proportionality review. In some jurisdictions, proportionality is wheeled out for use in a discrete set of contexts only, whereas in others, proportionality is recognized as a constitutional principle or general principle of law. But even in systems where proportionality in principle applies across the board, in practice it does not dominate administrative litigation, since other normative controls over administrative power are also in place. Regardless of the formal status of proportionality principle, there are some "usual suspects": legal contexts in which proportionality frequently turns up, wherever else it might appear. These include the review of administrative penalties, and administrative actions that implicate rights or other sensitive individual interests.

It makes sense that these would be areas of law where the use of proportionality is prominent. These are areas in which the stakes of government overreaching are especially palpable, because individuals are directly and adversely affected in salient ways. Under these circumstances, the appeal of a formula for review that blocks inappropriately far-reaching measures is intuitive and powerful.

The use of proportionality has expanded outward over time, both across legal systems, and within legal systems. There are reasons that favor proportionality's spread, but also factors that may check the breadth of its adoption to a greater or lesser degree in different legal systems. There are both strategic and normative logics to 
proportionality's spread (Stone Sweet and Mathews 2008). For judges, proportionality review offers a useful and flexible set of tools for managing difficult dispute-resolution environments. The proportionality framework offers a court an opportunity to acknowledge the validity of the competing interests on either side of a dispute and to justify its own decision with reference to the particular circumstances of the case.

What is more, proportionality is subject to a kind of hydraulic normative logic. Once courts declare that some administrative uses of discretion should be reviewed from proportionality, declining to extend proportionality review to other discretionary choices is tantamount to conceding that disproportionate actions are permissible some of the time. Courts may find it difficult to justify that result (although the task may be easier to the extent courts can rely on wellestablished doctrines curtailing the scope of review).

At the same time, national differences of several kinds stand in the way of anything like a convergence with respect to the scope of proportionality's application. Administrative law doctrines that are already in place will shape how proportionality is received in a legal system. More broadly still, structural features in administrative law systems determine what kinds of administrative decisions are in principle subject to judicial review, and may exclude important classes of decisions. ${ }^{20}$

Moreover, both formal and functional differences in the scope of judicial review and the role of courts vis-à-vis the administration can condition how extensively proportionality is used. Systems with strong norms against substituting judgment may be especially resistant to the use of anything like proportionality to review policy-sensitive judgments thought to lie within the administration's expertise. And courts that lack meaningful independence may be in a poor position to review the proportionality of high-stakes, politically salient choices. It would be surprising, for instance, to find courts in China exerting meaningful proportionality review over eminent domain decisions, as we see in France, given the limited independence that Chinese courts enjoy as a practical matter. ${ }^{21}$

\section{1.b Intensity}


Some patterns also emerge with respect to the intensity of proportionality review. To be sure, there is a considerable amount of residual variability as well, with the stringency of review varying for idiosyncratic reasons in some contexts. But in systems where proportionality is well-established, we see courts calibrating the intensity of review to the circumstances of the litigation, according to more-or-less explicit and intelligible formulas. Courts tend to be more deferential to the decision maker's choice of measure to the extent that those choices implicate policy judgments, or administrative expertise, or the management of risk. Courts are more likely to apply proportionality full strength to the extent that the measures under review threaten harm to individual rights or other favored interests.

In fact, it may that having some rubric for varying the intensity of review is necessary if proportionality is to become a prominent feature in a jurisdiction's administrative law. Applied most strictly, proportionality review leaves no room for deference to the judgments of primary decision makers. But this most demanding form of review will be a non-starter in contexts in which those judgments are deemed to deserve at least some weight. On the other hand, varying the intensity of review on a purely ad hoc basis opens courts to charges of unpredictability and arbitrariness.

Accordingly, it makes sense that systems in which proportionality is prominent typically devise some framework to regularize how the intensity of review varies. The amount of attention given to the problem of controlling the variable intensity of review within a legal system may be one indicator that the system is reaching the saturation point with respect to proportionality.

\section{1.c Discursiveness}

There also appear some underlying regularities to variations in the discursiveness of proportionality review. Proportionality can function as a justification structure courts can use to justify their rulings through systematic, reasoned appraisal of the challenged measures. The norms of judicial decision-writing may be more or less congenial to this use of proportionality in different systems, and the importance of reason-giving may vary as well. 
The extent to which courts use proportionality review as an opportunity to ventilate, in their written decisions, the appropriateness of a challenged measure will obviously differ depending on these system-specific features. But two further points are worth noting. First, even in systems where stripped-down, syllogistic decisions are the norm, courts can still find room for a proportionality analysis that shows off how the court carefully tested the challenged measure's fit. And second, courts across systems can expand and contract proportionality review like an accordion, depending on how much justification the court deems its conclusion to require.

\subsection{Proportionality's Place in Public Law}

If the brief survey above demonstrates anything, it is that proportionality review is readily adaptable to a host of different circumstances. Courts can dispense with elements of the standard model and conduct review more or less stringently, while still retaining the core idea of an appropriate relationship between means and ends.

But if proportionality's protean character is one of the secrets of its success, it is not the only one. The widespread adoption of proportionality review within administrative law systems also reflects the normative attractiveness of the proportionality ideal as a benchmark for judging state behavior. As described above, Prussian police law scholars articulated a legitimating logic for proportionality that reduces to two key propositions: first, that what legitimates the use of public power is the pursuit of public purposes, and second, its corollary, that exercises of public power should extend no further than those purposes require. These propositions continue to resonate, including in modern liberal democracies, and can justify the use of proportionality to test government measures that constrain private liberties.

While the adjudication of constitutional rights claims and the review of administrative discretion typically occur within separate doctrinal boxes, this rationale for proportionality applies in principle to both. And in systems where the use of proportionality is well-developed, the distinction between proportionality as a principle of constitutional law and as a principle of administrative law can erode. The paradigmatic example is Germany, where the constitutional proportionality 
principle has essentially absorbed the proportionality principle anchored in police law.

When proportionality makes frequent appearances in both constitutional and administrative contexts, it begins to look more like a general organizing framework for the review of government measures. On this view, constitutional rights claims are distinctive in that they are the basis for challenge to a wider range of government actions (for instance, to legislative as well as administrative action) and because they trigger particularly searching review. But, from this perspective, they can be regarded essentially as special manifestations of a more general government obligation to act proportionately.

Courts and other institutions face decisions that will determine whether and to what extent their legal systems embrace proportionality as a sort of master concept of public law. These questions are already coming up. For instance, in Canada, the issue of proportionality's scope and how it bears on the relation between constitutional law and administrative law has arisen in a number of cases in recent years, which have divided its Supreme Court (Walters 2015). ${ }^{22}$ Rejecting some calls for a broader rapprochement between constitutional law and administrative law, the Court has most recently adopted the position that proportionality does not apply as such to reviews of administrative discretion, but does inform the administrative law reasonableness analysis, insofar as administrative measures implicate the values of Canada's Charter of Rights and Freedoms. ${ }^{23}$

The Supreme Court of Canada's decisions serve as a reminder that the place of proportionality in public law remains contested in many systems. While some functional and normative logics augur in favor of generalizing proportionality into a kind of all-purpose criterion of legal legitimacy, a broad set of countervailing factors generate significant and enduring cross-national variations in when and how proportionality review is actually conducted. 


\section{References}

Alexy, Robert. 1986. "Ermessensfehler," JuristenZeitung 41 (15/16): 701-16.

Baade, Björnstjern, Sebastian Ehricht, Matthäus Fink, Robert Frau, Mirka Möldner, Isabella Risini, and Torsten Stirner, eds. 2016. Verhältnismäßigkeit im Völkerrecht, Mohr Siebeck.

Barak, Aharon. 2012. Proportionality: Constitutional Rights and their Limitations, Cambridge: Cambridge University Press.

Bomhoff, Jacco. 2013. Balancing Constitutional Rights: The Origins and Meanings of Postwar Legal Discourse, Cambridge: Cambridge University Press.

Brown, L. Neville, and John S. Bell. 1998. French Administrative Law, Oxford: Oxford University Press.

Bücheler, Gebhard. 2015. Proportionality in Investor-State Arbitration, Oxford University Press.

Carter, Geneviève. 2004. "The Baker Effect: A New Interface Between the Canadian Charter of Rights and Freedoms and Administrative Law-The Case of Discretion," in David Dyzenhaus, ed., The Unity of Public Law, 61-86, Oxford: Hart Publishing.

Chan, Cora. 2013. "Proportionality and Invariable Baseline Intensity of Review," Legal Studies 33 (1): 1-21.

Chikushi, Keiichi. 2013. "Prohibition of Underregulation: The Proportionality Analysis in Inaction Cases in Japan," Institutum lurisprudentiae, Academia Sinica, Workshop on Comparative Administrative Law in Asia.

Cohen-Eliya, Moshe, and Iddo Porat. 2013. Proportionality and Constitutional Culture, Cambridge: Cambridge University Press. 
Craig, Paul. 2006. EU Administrative Law, Oxford: Oxford University Press.

Craig, Paul. 2013. "The Nature of Reasonableness Review," Current Legal Problems 66 (1): 1-37.

Craig, Paul, and Gráinne De Búrca. 2011. EU Law: Text, Cases, and Materials, New York: Oxford University Press.

Craig, Paul P. 2017. "Proportionality and Judicial Review: A UK Historical Perspective," in Stefan Vogenauer, ed., General Principles of Law: European and Comparative Perspectives, Oxford: Hart Publishing.

Davies, A.C.L., and J.R. Williams. 2016. "Proportionality in English Law," in Sofia Ranchordás and Boudewijn Willem Nicolaas de Waard, eds., The Judge and the Proportionate Use of Discretion: A Comparative Study, 73-108, Abington: Routledge.

De Búrca, Gráinne. 1993. "The Principle of Proportionality and its Application in EC Law," Yearbook of European Law 13 (1): 10550.

Dyzenhaus, David. 2004. The Unity of Public Law, Oxford: Hart Publishing.

Fleiner, Fritz. 1928. Institutionen des deutschen Verwaltungsrechts, Tübingen: Mohr.

Huang, Cheng-Yi, and David S. Law. 2014. "Proportionality Review of Administrative Action in Japan, Korea, Taiwan, and China," in Francesca Bignami and David Zaring, eds., Research Handbook in Comparative Law and Regulation, Northampton: Edward Elgar.

Huscroft, Grant, Bradley W. Miller, and Gregoire Webber, eds. 2016. Proportionality and the Rule of Law: Rights, Justification, Reasoning, Cambridge: Cambridge University Press.

Jarass, Hans D., and Bodo Pieroth. 2012. Grundgesetz für die 
Bundesrepublik Deutschland, Munich: C.H.Beck.

Klatt, Matthias, and Moritz Meister. 2012. The Constitutional Structure of Proportionality, Oxford: Oxford University Press.

Lasser, Mitchel de S.-O.-I'E. 2005. Judicial Deliberations: A Comparative Analysis of Judicial Transparency and Legitimacy, New York: Oxford University Press.

Lin, Chun-Yuan. 2013. "An Unprincipled Principle? The Principle of Proportionality in Environmental Law in Taiwan and EU," Institutum lurisprudentiae, Academia Sinica, Workshop on Comparative Administrative Law in Asia.

Marsch, Nikolaus, and Vanessa Tünsmeyer. 2016. "The Principle of Proportionality in German Administrative Law," in Sofia Ranchordás and Boudewijn Willem Nicolaas de Waard, eds., The Judge and the Proportionate Use of Discretion: A Comparative Study, 13-42, Abington: Routledge.

Mathews, Jud. 2016. "Searching for Proportionality in American Administrative Law," in Sofia Ranchordás and Boudewijn Willem Nicolaas de Waard, eds., The Judge and the Proportionate Use of Discretion: A Comparative Study, 160-90, Abington: Routledge.

Maurer, Hartmut. 2011. Allgemeines Verwaltungsrecht, Munich: C.H.Beck.

Rose-Ackerman, Susan. 1995. Controlling Environmental Policy: The Limits of Public Law in Germany and the United States, New Haven: Yale University Press.

Sanchez, Yoan. 2016. "Proportionality in French Administrative Law," in Sofia Ranchordás and Boudewijn Willem Nicolaas de Waard, eds., The Judge and the Proportionate Use of Discretion: A Comparative Study, 43-72, Abington: Routledge.

Stern, Klaus. 1993. "Zur Entstehung und Ableitung des Übermaßverbots," in Peter Badura and Rupert Scholz, eds., Wege und Verfahren des Verfassungslebens: Festschrift für Peter 
Lerche zum 65, 165-75, Munich: C.H.Beck.

Stone Sweet, Alec, and Jud Mathews. 2008. "Proportionality Balancing and Global Constitutionalism," Columbia Journal of Transnational Law 47 (1): 73-165.

Tridimas, Takis. 1999. "Proportionality in Community Law: Searching for the Appropriate Standard of Scrutiny," in Evelyn Ellis, ed., The Principle of Proportionality in the Laws of Europe, 65-84, Oxford: Hart Publishing.

Tridimas, Takis. 2006. The General Principles of EU Law, Oxford: Oxford University Press.

Tsakyrakis, Stavros. 2009. "Proportionality: An Assault on Human Rights," International Journal of Constitutional Law 7 468-93.

Waard, Boudewijn Willem Nicolaas de. 2016. "Proportionality in Dutch Administrative Law," in Sofia Ranchordás and Boudewijn Willem Nicolaas de Waard, eds., The Judge and the Proportionate Use of Discretion: A Comparative Study, 109-41, Abington: Routledge.

Walters, Mark D. 2015. "Respecting Deference as Respect: Rights, Reasonableness and Proportionality in Canadian Administrative Law," in Hanna Wilberg and Mark Elliott, eds., The Scope and Intensity of Substantive Review: Traversing Taggart's Rainbow, 395-422,

Wang, Jing. 2013. "Proportionality's Blooming and Development in China," Institutum lurisprudentiae, Academia Sinica, Workshop on Comparative Administrative Law in Asia.

Webber, Gregoire CN. 2010. "Proportionality, Balancing, and the Cult of Constitutional Rights Scholarship," Canadian Journal of Law and Jurisprudence 23 (01): 179-202.

${ }^{1}$ Assistant Professor, Penn State Law. 
2 Major books devoted to proportionality that have appeared within the last five years alone include titles by Barak (2012), Bomhoff (2013), Cohen-Eliya and Porat (2013), Huscroft et al. (2016), and Klatt and Meister (2012). Critical treatments of the use of proportionality include Webber (2010) and Tsakyrakis (2009).

3 It is also worth noting that this chapter focuses exclusively on proportionality as a form of judicial control over administrative action. There are avenues besides courts for bringing the proportionality principle to bear. For instance, in China, the powerful State Council issued guidelines in 2004 that in essence instructed administrative bodies to exercise discretion proportionately (Huang and Law 2014, 25). For that matter, while the presidential rulemaking review conducted in the United States under the auspices of the Office of Management and Budget does not impose a proportionality test, its mandate to agencies to demonstrate that their measures are costjustified is broadly similar in spirit.

${ }^{4}$ For a recent and very useful volume concerning proportionality in administrative law in a number of (principally European) jurisdictions, see Waard (2016).

${ }^{5}$ Ben-Atiyah v. Minister of Education, Culture \& Sports, HCJ 3477/95 [1995] IsrSC49 (5) 1, 9.

6 Indeed, this statement does not go quite far enough. Because provisions of the private law are also subject to constitutional control, proportionality can also be used to mediate between competing individual rights in private party disputes. What is more, proportionality also applies to some conflicts over the competencies of different organs of the state.

${ }^{7}$ For a detailed consideration of the nature of errors of discretion, and their relation to the principle of proportionality, see Alexy (1986).

${ }^{8}$ Doré v. Barreau du Québec, [2012] 1 SCR 395.

9 Huifeng Industry Development Co., Ltd. v. Harbin City Planning Bureau, Judicial Decision No. 20 of Supreme People's Court (1999). The case concerned a local planning bureau's order that required 
partial demolition of a building that obstructed a historic site. The Court sustained a lower court's ruling that the order was excessive and invalid insofar as it required more demolition than necessary to eliminate the obstruction.

${ }^{10}$ See Paonette v. Attorney General of Trinidad and Tobago (2010) UKPC 32 (2012) 1 AC 1, (38).

${ }^{11}$ Benjamin, CE, May 19, 1933, Rec. Lebon 541. More recently, the Conseil d'Etat upheld a mayor's cancellation, on grounds of maintaining public order, of a performance by Dieudonné, a comedian known for his anti-Semitic statements. Dieudonné, CE, Jan. 9, 2014.

${ }^{12}$ Vinolay, CE, July 26, 1978.

${ }^{13}$ See decision no. 2008-562 DC, Feb. 21, 2008.

${ }^{14}$ C-491/01 British American Tobacco (Investments) and Imperial Tobacco [2002] ECR I-11461.

${ }^{15}$ For more on the circumstances associated with greater or lesser deference, see Tridimas (1999).

${ }^{16}$ Decision no. 2012-647 DC, Feb. 28, 2012.

${ }^{17}$ CE, no. 390441, Jan. 7, 2016.

${ }^{18}$ See, for instance, Bundesverwaltungsgericht, 8 C 13.09, Nov. 11, 2010.

${ }^{19}$ See, for instance, Bundesverwaltungsgericht, 6 C 10.09, Apr. 15, 2009.

${ }^{20}$ For instance, Article 13(2) of China's draft Administrative Litigation Law makes challenges to regulations inadmissible.

${ }^{21}$ While eminent domain decisions in China are subject to review for rationality as well as for legality, as a practical matter this review is very limited. Thanks to Yuejun He of Ningbo University for this point.

${ }^{22}$ Key cases include Doré v. Barreau du Québec, [2012] 1 SCR 395, 
Multani v. Commission scolaire Marguerite-Bourgeoys, [2006] 1 SCR 256, Suresh v. Canada, [2002] 1 SCR 3, and Baker v. Canada (Minister of Citizenship and Immigration), [1999] 2 SCR 817. Essays on the Baker case are collected in a volume tellingly titled The Unity of Public Law (Dyzenhaus 2004).

${ }^{23}$ Doré, supra note 32. 